Gadjah Mada International Journal of Business

January 2004. Vol. 6. No. 1, pp. $45-64$

\title{
SOME CHALLENGES TO THE ENFORCEMENT OF THE COMPETITION LAW IN INDONESIA ${ }^{*}$
}

\author{
Syamsul Maarif
}

Indonesian competition law known as Law No. 5 of 1999 was adopted on the fifth of March 1999 and took effective a year later, the fifth of March 2000. Since the adoption of the Law we are witnessing business players have changed in the ways they run their businesses. We are also witnessing challenges that need to be dealt with if we want Law No 5 effective to reach its objectives. This article discloses some of those challenges. The most difficult one to deal with is the resistance by the court to the existence of the Indonesian Antimonopoly Authority (KPPU).

Keywords: competition law; competition policies; district courts; law enforcement; supreme courts

* A short version of this paper was presented by the Author at the Twenty-Ninth Annual International Conference on Antitrust Law and Policy, October 31 and November 1, 2002 Fordham University New York. USA. 


\section{Introduction}

During the first year of its implementation, Law Number 5 of 1999 encountered a variety of opinions from different segments of society. Many have misunderstood the objectives of the law, believing its primary purpose is to go after big companies and protect small and mediumsized business enterprises (PBC 2000). Apart from misunderstanding the law's purpose, many also have been skeptical about the existence of the newly appointed commission - Supervision of Business Competition ("Komisi Pengawas Persaingan Usaha or KPPU")- here after the Commission. Along with the judicial and law enforcement problem in Indonesia, the Commission carries a substantial burden in socializing the law and introducing its existence, mechanisms, and objectives as Indonesia's primary competition law enforcement agency. At the same time, as a newly formed public institution, the Commission encountered organizational problems in terms of its infrastructure, budget, and developing a skilled bureaucracy (KPPU 2001).

As newly adopted positive law, Law on Prohibition of Monopolistic Practices and Unfair Business Practices or known as Law No 5/1999 has been implemented in less than four years. During its early enactment, interested parties believed that the law has been experiencing complexity and obstacles (Fox 2002; Sjahdeini 2000; Silalahi 2001; Wie 2000; Hansen K, et al. 2002). The author believes that this is considered to be a common phenomenon in a newly adopted regime of law.' After three years of enforcement, like in most countries, amendment of the law seems to be an alternative. However, by come across the substance of the Law UU No. 5/1999, we may have agreed that the substance is quiet comprehensive and could become an effective tool to improve the atmosphere of business practices in Indonesia. The comprehensive material of the law covers almost all aspects, which hinder the business actors to evade the law. Law No. 5/ 1999 regulates not merely the substance but also touch on the structure of the institution, which enforced the law itself.

The enforcement of Law Number 5 of 1999 is vested in the Commission for the Supervision of Business Competition, which is authorized to prosecute violations of the law. The Commission's core functions include: (1) law enforcement, through investigating, interpreting, and enforcing the law, and (2) competition advocacy, that is providing advice on government policy related to monopolistic practices and unfair business competition as well as issuing written guidelines and policy statements intended to assist business and the public to understand and comply with the law.

Another important section of the law defines the formation, structure, and mandate of the Commission (Articles 30-49, Law No. 5/1999). The Commission is the Indonesia's first independent regulatory commission, and it is not a part of the executive, legislative, or judicial branches of government. The Commission may investigate alleged violations of the law either as a result of formal complaints, or it may open an investigation upon its own initiative (Maier 2001).

In comparison with similar commissions in other countries such as the United States, Australia, and Japan, the law provides the Commission with a broad man-

'The author applied the term of "challenges" instead of "obstacles" since challenges seem to be in more positive approach rather than obstacles. 
Maarif - Some Challenges to the Enforcement of the Competition Law in Indonesia

date. This mandate appears to include matters that touch upon the competency of the courts, such as imposing criminal sanctions on wrongdoers. ${ }^{2}$ Common practice in the Indonesian legal system is that decisions involving criminal sanctions are solely the province of the court. Although the debates among Indonesian scholars on how to interpret the mechanism that the Commission conferred with competency to provide criminal sanctions or not, the ambiguity still arises in the discussion both for the question of the competency and the process of adjudication (Brietzke 1999; PBC 2001).

The law has been enacted in less then four years, therefore it difficult to justify, which aspects have been fail to upheld and the lesson learned has not been shown significantly. However, the author noted that there are several points which should be taken into account which covers the conceptual issues as well as the enforcement. This paper is based on the individual experience as a member of the Commission for Business Competition (Komisi Pengawas Persaingan Usaha-KPPU). The critic does not reflect the pessimism towards the effectiveness of Law No. 5/ 1999 , but it should be read as the pledge for the experts to extend comments to respond to the future challenges of Law No. 5/ 1999.

\section{Conceptual Challenges}

The conceptual challenge in this contexts means as consequences because of the concept or principles embedded existed and applied within the contents of the Law No. 5/1999. The conceptual challenges among others, consist of achieving various purposes and objectives of the law, improvement of the business law approach, flexibility in competition law enforcement, and the possibility to enforce administrative sanctions towards the government officials who involved in the breaching of the law.

\section{Objectives and Purposes of the Law}

The first challenge is relevant to the achievement of the various purposes of the law as stipulated in Article 3 of Law No5/ 1999. ${ }^{3}$ Literally it is difficult to understand Article 3 due to its many objectives between what so called approach and the purposes. Efficiency is the objective, however the fair business practices should be considered as an approach. When the law applied two different aspects in one article, it will entail problems and difficulties in terms to understand and to distinct the meanings.

The concept embedded in Article 3 also does not provide clear distinction between the short and long term objectives

\footnotetext{
${ }^{2}$ Articles 47 - 49 Law No.5/1999 delineate the sanctions that may be imposed by the KPPU, however in Article 48 \& 49, it has not been clear if criminal sanctions would be imposed by the KPPU but certainly there has no literally mentioning the court in the context. However, this assumption or understanding appeared in the beginning of the enactment of the law in 1999. The debates is still in progress up to now among the scholars and judges, although in many forms of KPPU presentation, KPPU Commissioners clearly stated that the court including police as investigators would take the role when the matter of criminal issues arises in the case.

3 Article 3 of the Law No.5/1999 stated that: The objectives of this law are: (a) to maintain public interests and improve the efficiency of the national economy as one of the means to improve public welfare; (b) to create a conducive business climate through healthy business competition, thus securing equal business opportunity for large, middle and small scale entrepreneurs; (c) to prevent monopolistic practices and/or unfair business competition by the entrepreneurs; (d) and to create effectiveness and efficiency in business activities.
} 
or goals. For example, the objective of improvement people's welfare is included in the long-term goal, while improvement of national economic efficiency is written in the short-term goal. Therefore the Commission bear a hard task in terms of digesting the focus of objectives of the law, where some critics argued that the objectives of the law were not focus and unclear (Basri 2002).

The author thinks that although the law does not provide clear or focus objectives, however, the purposes of Law No. 5/ 1999 consist of two aspects, which covers competitive and non-competitive issues (Adiwiyoto 2001). What constitutes the objectives of competition here is the achievement of the efficiency in business practices. This is understood to be parallel with objectives of various competition laws in many countries, which is to obtain efficiency. While the non-competitive objectives is to maintain public welfare [Article 3 point (a)].

Therefore, it is important for the Commission to accommodate both objectives, although they are different in their approach. The author believes that this is not easy to implement if the wording of public welfare in Article 3 is understood not as consumer's welfare.

The Commission would encounter difficulties in obtaining the decision if the public welfare here is interpreted as the issues of employment opportunities. The two purposes, to achieve efficiency and employment opportunity would be difficult to combine together, especially in term of short-term goal. For the efficiency purpose, the management decision would be acceptable to down sizing its employees. However in term of achieving efficiency, the management decision to con- duct merger, with similar company or its competitor, usually followed by termination of its employees. However, some might argue that the rationalization or merger would not be acceptable in the approach of the employment seekers due to its implication of triggering the unemployment ratio. ${ }^{4}$

The Commission also encounters difficulty in absorbing the decision whether the public interest in Article 3 should be understood as stability within the people's economy. If this were the consideration, therefore, the Commission would be reluctant to invalidate or not to approve a merger, which may cause unfair business practices if the implication may trigger high unemployment.

The Commission could also be bias when deciding the case if the public interests in Article 3 shall be construe as the protection to certain business actors. This may be existed within the industry with oligopoly structure, where few small medium businesses through exclusive agreement may become dependent to the big business in terms of capital, technology, or marketing. The Commission may become uncertain in delivering their decision to punish the oligopolies and the exclusive agreement if it will trigger the small medium business would be out of business. This may occur the Commission reads and understands that the objective in Article 3 and the issue of public interest means to protect business actors interests.

The author believes that the public interests in Article 3 shall be construe as the consumer welfare. This is based on the ultimate beneficiaries of the competition are consumers. However, the author has not found sufficient reference both from academic or practice in various countries

${ }^{4}$ Efficiency substance has been discussed in many expert papers, see Posner (1992: 277- 280). 
Maarif-Some Challenges to the Enforcement of the Competition Law in Indonesia

to conclude that public interests the is the term applied in many countries and understood as the interests of the business actors.

Competition law is not meant as the tool to protect the business actor's interest, however, it is to protect the competition process itself. Therefore the means of business actor interests would also include the interests of small medium business enterprises. The interests of various players would be automatically protected if the competition law could be effectively enforced since the big player would not be able to abuse its power in the market to create barrier to entry for potential new competitors.

The author thinks that the term public interest in the view of small medium business and other public interests has been accommodated or covered through other articles such as in the exemptions clauses. For example in Article 5, point (2) and (b) is to protect the public interest in terms of price fixing. ${ }^{5}$ Article 50 (a) applied to regulate the business under the existing law. "While Article $50(\mathrm{~h})$ applied to the need of small medium business. ${ }^{7}$ On the other hand. Article 51 is aimed to accommodate the public interests, which relates to goods and services. ${ }^{8}$ Therefore, in the author's opinion, the Commission shall not be burden with direct consideration the public interest's issue if the matter is not directly relevant to the problems regulates in the articles of the law.
The best alternative that the Commission could do in a case if the complaint based their report on the argument to protect the interests of the small medium? Would the Commission be better off by not considering or take into account at all the argument?

The author thinks that the Commission should be able to touch on that consideration, since in Article 3, stipulated that Law No. $5 / 1999$ shall be the tool to improve business atmosphere which literally means to provide equal opportunities for big, small medium business. However, the Commission shall formulate mistake if for the sake of small medium business, the defendant shall be punished even they did not perform something which is considered breaching or against the law.

Business activities which substantively are not considered to breach the law, however, considerably is distressing to the small medium business or considered as non-violations actions need to be examined carefully. The commission approach would be through regulating the behavior and not through punishment. The Commission has done this through the decision recently in the Indomaret case. In this case, the Commission Assembly has not found any illegal wrongdoing in the context of substantive of the law, however the Commision found and proved that the defendant has been destructive to the continuity of the small stores existence around the area. Therefore, the Commission As-

\footnotetext{
3 Article 5 point (2) (b), Law No.5/1999, in essence, price fixing could be exempted and shall not be applicable for the following ... (b) an agreement which based on the existing law or positive law".

"Article 50 point (a) stipulated that conduct or agreement exempted from Law No.5/1999 are "conduct or agreement with the purpose to execute or implement the existing positive law".

${ }^{7}$ Article 50 point $(\mathrm{h})$ stipulated that the small medium business shall be exempted from Law No.5/1999.

${ }^{*}$ Monopoly and/or centralization of activities related to the production and/or marketing of goods and/or services which control the needs of people in general and production branches vital to the state shall be regulated under the law and shall be performed by the State Owned Companies and/or entities or institutions established or appointed by the Government.
} 
sembly did not punish with the sanctions but merely regulate that in the future. That is, if the defendant plans to expand the business, they shall not expand it surround or opposite the location where small medium business exist.

To avoid misperception and uncertainty, therre seems to be the need to revise Article 3 especially on the part of the objectives. In the revision, non- competition objectives should be eliminated and the objectives of the Law No. 5/1999, which is to create an efficient economy for overall welfare of the people must be clearly stressed. This emphasis will not put the Commissioners in the burden to solve income distribution or an employment creation or the protection of small enterprises. These last three issues fall outside the jurisdiction of competition law.

In the revision it should also be emphasized that the term public interests in Law No. 5 is also the consumers' interests. This emphasis is needed particularly to reduce various possibilities on the interpretations that in reaching its verdict, KPPU must also consider the security of the people. If one thing or another revision cannot be conducted, the alternative is that for KPPU to exercise its authority especially in interpreting the objectives of the Law No. 5/1999. Through its decision, KPPU interprets that the objectives of the Law No. $5 / 1999$ is to reach efficiency for the consumers' well- being and public in general.

\section{New Approach in Business Law}

The second challenge is relevant to the legal reform versus legal tradition in Indonesia. There was an opinion that Law No. 5/1999 would be difficult to be en- forced because the law does not provide clear procedural law both in civil or criminal procedure, especially in terms of civil procedure. There has been lot of questions arise since there has no clear explicit explanation on the procedural process, whether competition law process may be treated differently from common procedural law. However, since the law encompasses criminal sanctions, this could literally means that the procedure may follow or apply the common criminal procedure law as in Kitab Undang Undang Hukum Acara Pidana, or KUHAP, and when such allegation arise, the case would be proceed through police (investigators), prosecutors and to the court."

The author, however believes that the civil code has been agreed that it would only be used as the guidance as long as the procedure has not been available. The author viewed this as opinion, which conflicted between the legal reform and the legal tradition. If we base our thinking on the legal tradition, therefore, Law No. 5/ 1999 then we will perceived this law according to the previous approach and not as a tool to improve for the new legal reform.

As a new regime, it is admitted that Law No. 5/1999 regulates lot of new aspects of the law and that includes the substantive in material, formal and institutional. Relevant to the substantive material, Law No. 5/1999 introduces many prohibitions to the existing business practices or agreements, which may cause monopolistic practices and unfair business practices. There are at least 23 substantial prohibitions, which may apply rule of reason or per se illegal approach (Maarif 2002; Kaplow 1997: 165-250; ABA 1977).

\footnotetext{
'In-depth interview with Commercial Court Judge, Elyta Ras Ginting, Medan, January 2002.
} 
Maarif - Some Challenges to the Enforcement of the Competition Law in Indonesia

The new material approaches filled the niche of law with the aim to regulate the business behavior. Prior to the enactment of Law No. 5/1999, individuals which are injured by other business actors may file a complaint to the District Court based on Article 1365 Civil Code. ${ }^{10}$ However, the question arises, with the existence of law No. 5/1999 would Article 1365 of the Civil Code could still be used to regulate the business actors' behavior?

The answer shall depend on how we read and understand Law No. 5/1999. If we perceived as a way or a tool of legal reform in business law, therefore the answer would be that Article 1365 of Civil Code would not be necessary anymore. There is a comprehensive law, which regulates the monopolistic practices and unfair business practices. However, this does not reflect that Article 1365 of Civil Code does not exist any longer because this article could still be used for other approach of anti competitive behavior or conduct.

The concept seems simple, however, the approach is considered significant on how we perceived and understand Law No. 5/1999. For example, the approach shall determine how Judges in District Court shall decide on the case taken to the court under Article 1365 Civil Code how- ever the case is actually is in fact is competition case. Judges may refute to hear before the case and advise the parties to submit their case to the Commission instead. However, this would only possible if the Judges perceived the law with the legal reform approach. Subsequent to that, if the Commission then decided that there is violation of the law by the business actor, therefore another party may also use the Commission decision to submit their claim by using Article 1365 Civil Code.

Similar question arise with regard to Article 382 bis Criminal Code." Would this article still be in use to control the business actor behavior subsequent to the enactment of Law No. 5/1999? Once again the answer would depend on how we perceived Law No. 5/1999. Would we view Law No. 5 has supersede Article 382 bis Criminal Code because the principles has been adopted in by Law No. 5/1999? If this approach adopted, the investigators then could possibly refuse to conduct investigation if they know that the case would fall under Law No. 5/1999 jurisdiction and they would suggest that the petitioner would be better to submit their claim to the Commission.

Misunderstanding to read the concept and approach could implicate in the effectiveness of Law No. 5/1999, espe-

${ }^{10}$ Article 1365 Civil Law: "Each conduct which prove to be against the law and brought loss to other people, that person shall be liable for paying the redemption for replacing the damage". As comparison, other basis that could be used as the ground, materially could be found in Law Number 5 of 1984 on Industry, Article 7 which states that The law states that "The government shall regulate, supervise and develop industry for: "(2) expanding fair competition and avoiding unfair competition practices (3) avoiding centralistic economy and exploitation of industry by few or only one business actors in form of monopolistic practices, which in the long run would injured the. Article 9 point (2) Regulation and supervision of industry shall be executed by considering: (2) Creating fair business atmosphere for industrial growth and avoiding unfair business practices between companies in the same industry, to avoid and evade centralistic of economic power by one or few companies or business actors in form of monopolistic practices.

" Article 382 bis Criminal Code states that anyone obtaining, executing or expanding a business or own company or other people company, conducted unfair business practices and deceived public or party, shall be punished because of unfair business practices with penalty of maximum one year four months or with fine of maximum of $R p$ 13,500,-if it is prove to be injurious to its competitor or other people. 
cially in the development of business law in Indonesia. For example, if Judges in District Court would still accept to hear the case based on Article 1365 Civil Code, therefore it will be possible to have a case concurrently both in the court and at the Commission. It will also be possible to have 3 investigations in the same time if the investigator decides to apply Article 382bis Criminal Code, although all of these issues have been covered under Law No5/1999.

This would be more complicated if among the law enforcers issued different decisions. One can imagine if the Commission found there is violation and request the executorial decree to the court to enforce their decision and in the same time the District Court decide otherwise based on Article 1365 Civil Code?

Also what would happen if the Commission found there are a violation but the defendant did not execute the decision and therefore the Commission would submit their judgment to the investigator? While in the same time, based on Article 382bis Criminal Code, the investigator conducted investigation and did not find any violation of the law. Should the investigator proceed further based on the initial finding from the Commission while on the other hand, the investigation leads to no evidence of the violation?

The author believes that to avoid all misunderstanding and misconception in understanding the substance of the law, to make the law effective and enforceable, there is a need to have consistent percep- tion of Law No. 5/1999. The ambiguity could be avoided if the legal community perceived that Law No. $5 / 1999$ to be the tool for the legal reform in business law in Indonesia.

Beside the material substance, Law No. 5/1999 also introduced many new aspects pertaining to legal formal or legal procedure of the investigation with the Commission role. One of the issues is the role of the investigator. According to Law No. 5/1999 the investigator plays an important role in the enforcement process, however their role would be depending on the development or progress of the Commission investigation and the business actors mind-set toward the Commission decision.

Under the circumstances that the parties summoned by the Commission did not appear before them, therefore the Commission could request the investigator to summon the parties once again. ${ }^{12}$ Second, if the parties refused to submit their documents or information to the Commission, then the Commission may submit the uncooperative conduct to the police investigator according to the procedural law. ${ }^{13}$ The third, if the accused party did not comply or execute the Commission verdict, then the Commission would refer the case to the investigator (in this case is the police) to process further based on the existing criminal code procedural law. Another question that need attention is an executorial process within the context of an administrative sanction. The Commission shall obtain executorial consent from

\footnotetext{
13 Article 36 point (g) stipulated that: Authorities of the Commission are: requesting assistance from the investigators to bring the entrepreneurs, witness, expert witness or anybody as referred to under Paragraph $e$ and f of this article, who are not willing to fulfill the summon by the Commission to appear;

${ }^{13}$ Article 44, point (4) stipulated that: If provisions as referred to under Paragraph (1) and Paragraph (2) of this article are not carried out by the entrepreneurs, the Commission shall hand over the said decision to the investigators for investigation pursuant to the existing law.
} 
Maarif - Some Challenges to the Enforcement of the Competition Law in Indonesia

the court and would generate problems only if the party refuse to comply, for instance if the party refuse to cease the agreements or to stop their illegal behavior. However, the law is not clear whether the Commission decision must obtain an executorial consent either there is a challenge or not. ${ }^{14}$ As a comparison, Federal Trade Commission of the U.S., in the process of cease and desist orders, must seek enforcement in federal court (Mier 2001).

The regulation regarding the role of investigator in handling competition cases actually is clear and even yet very new. However, to make it works accordingly, that would much depend on once again, how we perceived the law. There is a question arise when there are two institutions who actually in fact posses the same competency, the Commission and the investigator. The common practice is that the investigator summoned the parties to appear before them to be questioned. However, the author believes that new approach in procedural law could be adopted to respond to the need. For instance, police have provided assistance during the investigation of Indomobil Sukses Internasional (IMSI) case of bid rigging for questioned in the Commission office.

Law No. 5/1999 also regulates new aspects relevant to the institution existence, especially as the quasi judicative body. Prior to the enactment of Law No. 5 , the District Court is the first authoritative body in deciding unfair business practice cases. The Appeal Court as the second level of the Court, then the Supreme Court as the final recourse. The procedure would be based either on Article 1365 Civil Code for civil claim or litigation or Article 382bis Criminal Code for the District Attorney to investigate the case.

Law No. 5/1999 introduced the Commission of $K P P U$ as the new authoritative body in deciding competition cases. Within the competition case, the Commission acting as the first judicative body which is equal to the District Court. The District Court acting as the second body in hearing the appeal from the business actors whenever they decide to contest the Commission decision. Therefore, the appeal proceeding would be proceed through the District Court and not through the Appeal Court. Then the final recourse would be at the Supreme Court competency.

These are all new approaches, therefore lot of questions arise. Some argue and some agree that the Commission should be treated and recognized as the authoritative body which posseses the competency to decide on the competition cases. Although the Commission is not a court or the investigator, however the Commission should be given deference and should be perceived as the proper institutional to resolve business matters due to its multifunction role. The Commission role also expected could speed up the outcome of the case. Again the author believes that the issue could be resolved if only there is consistent perception on how everyone read and understand the law. For instance, Judges should give deference to the Commission and respect their role by not deterring the Commission in implementing their constitutional role, such as to conduct investigation to the allegation of a wrongdoing. This consistent approach would lead all of us to view that the Commission shall

14 Article 46 Law Number 5 of 1999 stated that shall there be no contest or challenge from the party to comply with the decision, the Commission shall obtain consent for executorial order from the court. 
work and collaborate with the other law enforcers such as the police, investigators, prosecutors and judges.

To narrow down differences in comprehending new issues in the Law No. 5/ 1999 , there must be continuous effort to socialize the Law to various stakeholders, especially Law enforcers namely; the Police and Judges. Discussions therefore must be conducted between KPPU and these stakeholders with respect to understand how KPPU can exercise its power without causing any legal problems somewhere. Together with other Law enforcers, KPPU needs to coordinate its administrative actions in tandem with other Law enforcement activities, be it civil or criminal case. This collaboration is important to avoid legal uncertainties in Indonesia.

Coordination between institutions is very much needed to find solutions on any technical problems. For example that investigator in executing its task to summon certain parties to be examined by KPPU, there must be a strong definition and consensus as to how this activity can be financed. The financing of this activity can be put on the shoulders of KPPU or Police Department since they both get their budget from the State Budget. If the burden is shifted to the hands of Police Department, there must be a proposal in its yearly budget to attach funding needs to summon parties in the KPPU's examination. This is a technical matter but potentially can result into bigger problems if it is not coordinated in the correct manner.

\section{Nonlegal Approach}

The impact of any law command would depend on how it is interpreted, regulated and enforced. Similar to every other competition law in other countries, Indonesian competition law comprises similar sanctions such as administrative and criminal sanctions (Articles 47-49, Law Number 5 of 1990). Although under Law Number 5 does not clearly recognize private right of action, the Commission may, however, order the law violators to pay compensation for damages to injured parties [Articles 47 (2) f, Law Number 5 of 1990]. Additionally, private actions alleging anticompetitive conduct may still be brought under other laws as long as they are not contradictory to Law Number 5 and are not superseded by newer laws [Articles 52 (1), Law Number 5 of 1990]. Civil or private action, which are not using government institution encompass few articles in the law found scattered among few other regulations.

The next challenge is related to the approach of the competition law enforcement. There is a question that the Commission performance should be able to present itself not as a threat institution in its role or performance. This assumption is understandable since the Commission posses the competency to request the investigator to force the business actor to provide information if they refuse to collaborate. This action is endorsed by the law, in fact by reading the law entirely, Law No. 5/1999 seems to apply legal approach rather than policy approach.

The author found that this is not only existed in Indonesia. Similar to many countries, Law No. 5/1999 applies law enforcement with public action approach (see Posner 1992, supra note no. 8). With the public action approach, remedies would not be offer to an individual and petitioner's complaint would be process through the Commission. Similar to the prosecutor in criminal case, the Commission on behalf of the people proceeds with the complaint. Therefore, once the complaint has been filed, the report would become under the 
Maarif - Some Challenges to the Enforcement of the Competition Law in Indonesia

Commission competency and could not be revoked. Subsequent to the acceptance of the complaint, the Commission shall commence investigation to the allegedly accused party.

During the investigation, the parties must comply with the Commission order; otherwise the Commission may refer the case to the investigator. Subsequent to investigation, the Commission then decides on the decision whether there is violation of law or not. If proven to be guilty, the Commission then announcing the verdict. If the party refused to obey the verdict, the Commission shall choose to any of the two approaches. First, the Commission could request the executorial decree to the District Court or second, refer the case to the investigator. Then the investigator administered the case further by applying the Criminal Law Procedure.

From the above procedures, it seems that the Commission was given limited choices to use amicable settlement or to give amnesty to the business actors who agreed to plead guilty. Therefore, if a complaint regarded as Further Investigation stage, then there would be no alternative for the Commission to discontinue the investigation process and to issue a verdict, which is going to be done in the course of public hearing.

The author believes that this is the consequence of the public action law enforcement approach. In the public action regarding criminal case, similar concept applies, where there is no possibility of amicable settlement between the investigator and the allegedly wrongdoer. The party who agreed to plead guilty under Law No. 5/1999 would not lead to the amicable settlement and even more would not release them. In criminal case, plead guilty could be substantially influence the verdict render by the Commission. The assumption appears because the Commission applies similar approach and this makes the Commission features seems to be a threat institution.

However, the author agrees that the competition law enforcement should be implemented in the soft and flexible way. Therefore there is a need to develop a system which allow the Commission to grant reward and decease order to stop the investigation if the allegedly wrong party admitted, and promise that they would not repeat their conduct in the future and in the same time agree to pay the penalty or the compensation. This is important step so that the business actor would voluntarily adjust their conduct before the Commission renders the verdict.

The author believes that flexibility is required and is possible in the enforcement of Law No. 5/1999 since not all complaint would be proceed up to the investigation. The Commission would be able to stop the investigation and plead guilty is one of the many factors that could be used by the Commission to stop the case. In the United States, there is such procedure existes under so called settlement where the business actors principally admitted their conduct and willing to comply and pay the penalty to the Federal Trade Commission. Federal Trade Commission is an independent body with the competency to undertake investigation on antitrust cases. Further process would be continued if the party breached the commitment with the FTC.

This model of settlement could be developed more and the contents of the settlement will be made open to the public to enable the public could be well in- 
formed on the fairness of the process. The announcement will become necessary although does not necessarily through public like in the course of announcing the verdict or after the further investigation process has been completed.

Presumably there will be no problems anticipated if the enforcement would allow some flexibility as long as it leads to the improvement of the business actor behavior. The next challenge is to develop a mechanism that the flexibility and the settlement would not lead to the collusion between the Commission staff and the business actors.

\section{Sanctions for Government Officials}

The other challenge is relevant to the government support towards the application of the sanctions to the government officials who are involved in violation of Law No. 5/1999. Although it is not explicit, Law No. 5/1999 seems to limit the Commission jurisdiction to give sanctions that only apply to the business actors [see Article 1 point (18) and Article 47 Law No. 5/1999]. If the limitation applies, then the Commission would not be eligible to give sanction directly to an individual who is not a business actor, this include the Project Manager or Government Bidding' Committee who are not fall under this category.

This is also means that the Commission would not be eligible to summon the officials to give information before the Commission. According to Law No. 5/ 1999 , government officials who allegedly know that there is a violation of the law must be obliged to give information or provide documents during the Commission investigation process. ${ }^{15}$ This can hinder the purpose of Law No. 5/1999 especially in the government bid rigging case because even the Commission could prove that there is such violations existed, however the Commission could not give sanctions to the government officials.

This problem occurred during the bid rigging case in East Java Province under Cattle Import Procurement Project from Australia with the total amount of $14 \mathrm{Bil}$ lion Rupiah where the Commission has decided the case. ${ }^{16}$ The Commission Assembly found that there is bid rigging scheme existed among the bidders (Koperasi Pribumi Indonesia (KOPI) or Cooperatives of East Java with few government officials. The collusion appears in the form of the tour and trip together to Australia prior to the announcement of the bidding winner.

The Commission Assembly decide on the verdict that KOPI of East Java would not be able to participate in the similar bidding around 2 years. While the government officials, the Commission Assembly did give any sanctions. However, in the consideration, the Commission Assembly advised the Governor of East Java Province as the direct head to at least give administrative sanctions.

The administrative sanction seems powerless and even soft, because the Governor could also not implement the decision since it is only in the form of an advice. However, this is the maximum effort that the Commission can do so far, since the Commission does not posses any jurisdiction with regard to give sanctions

\footnotetext{
${ }^{15}$ During the course of this article. the Commission verdict is still pending and not yet hold final and binding decision, since the duration to submit the appeal is still pending.

is Similar note of the author, see also Maarif (2002).
} 


\section{Maarif - Some Challenges to the Enforcement of the Competition Law in Indonesia}

to the government officials but only to the business actors.

What would happen if the officials requested by the Commission to do the administrative sanctions refuse to comply? This can lead to a problem because in terms of improving the government bidding mechanism, there would be no party with clear jurisdiction who can give sanctions with regard to the violation of Article $22,{ }^{17}$ Law No. 5/1999. Violation in this term means bid rigging or collaboration to set the winner of the bidding and the violation is not fall under the prohibition of collusion, corruption and nepotism as regulated in Corruption Law. The authoritative body, which posses' competency is investigator and not the Commission,

This cannot be relevant to the sanctions as regulated the Presidential Decree No $18 / 2000$ on the Government Goods/ Services Procurement. The issue could be extended if the Commission could prove that there is such violation of the Presidential Decree No. 18/ 2000. Therefore it is possible that the substance of bid rigging could be proved under Article 22, Law No. $5 / 1999$ but could not be proven as violation under Presidential Decree No 18/2000.

For instance, in deciding the winner of the bidding would be directly decided by the tender committee for the bidder whose qualification is much under average other bidder. This is considered not a violation of Presidential Decree No. 18/ 2000 because for goods and services procurement is done through direct appointment and there is no specific requirement or standard for the mechanism. However, the direct appointment could be fall under the violation of Article 22 Law No. 5/1999 since the bidder with low qualification compare to other bidders shown that there is an unfair business practice existed. This can be occurred because the Bidding Committee set the mechanism by purposely set up that the all bidder would not comply with the qualification, therefore direct appointment would be required. In this conlext the Bidding Committee set up the bidding process and caused unfair business practices, however this can not be prosecuted under Presidential Decree No. $18 / 2000$.

This is the kind that the Commission encounters in the enforcement of Law No. 5/1999 especially when the Commission seeks support from the government officials to give administrative sanctions to their subordinates. There is no a quick fix in answering to this issue. First, there must be effort to revise the Law No. 5/1999. In that revision there must be strong confirmation with respect to the right of KPPU related to government officials involved the violation of the Law No. 5/1999 especially in the case of collusive tendering and the obligation of related institution to positively response on the KPPU findings. The alternative is, KPPU to be given the right to conduct investigation and make an announcement on the government officials who commit the abuse of positions and corruptions. The investigators from the Police Department or office of Attorney General are obligated to take actions on the KPPU's findings and submit those evidences to the court. The other alternative is KPPU to present evidence to the superior of the violators, so administrative actions can be taken and also the superior is obligated to report to KPPU as to how he can effectively achieve the assigned task in disciplining the violators. This solution will be effective if it is contained in the Law No. 5/1999.

\footnotetext{
${ }^{17}$ Article 22 stipulated that entrepreneurs are prohibited from conspiring with other parties to arrange and/ or determine the winner of the tender thus causing unfair business competition.
} 


\section{Implementation Challenges}

The implementation challenges in this contexts not by any means appear from the principles embedded in Law No. 5/1999, however more likely occur from the implementation during the enforcement stages. The challenges cover settlement of the case in the Commission level, obtaining information within the government official's level, allegation of the violation of the law in the region context, willingness to be a witness, obtaining written evidence and the role of the legal counsel in the competition cases.

\section{Settlement}

Supreme Court Justice, Professor Bagir Manan stated in one of the occasion that the Supreme Court wishes that in the future there should not be lot of competition cases will be taken to the Supreme Court for appeal. This is due to overload docket in the Supreme Court, which hardly handled by limited availability and number of Justices. Assigning more Justices to hear the cases seems not to be the best alternative to resolve the problem of case dockets. There is an idea of reforming the procedural law as the way out to resolve the high dockets in the Supreme Court by eliminating certain cases to be allowed to hear before the Justices. One of the criteria is through limitations of the economic value or figures of one case.

However this idea has been rejected because the consideration based on the economic assessment of a case does not necessarily reflect the value of justice. In Law No. 5/1999 there has no substance, which limits the assessment of a case, which can be decided by the Commission. The Commission's responsibility is to investigate objectively and render a fair verdict so the business actors would comply with the decision. Few of the senior Justices also put extended their hope that the Commission would do their best effort to implement the law objectively as a way to avoid appeal, which can resulted in the case dockets.

As a comparison, most of civil suits brought by the Department of Justice in the United States are settled through the "consent decree," a mechanism recognized in the U.S. court system. ${ }^{18}$ This kind of mechanism does not appear in the Law Number 5 of 1999. The decree could eliminate the costs of trial and generally include provisions for ending the conduct challenged in the complaint. Proposed consent decrees must be submitted for approval by the court where the complaint was filed. Consent decrees are almost always found to be in the public interest (Squerty 1995).

However, the defendant's challenge to the verdict would not be the only reason to submit their appeal to the District Court. The experience shows that the effort to find justice or the truth not the mere motive but also as litigation strategy, it is one of many ways to extend or delay the execution as the litigation strategy.

It is not easy to find solutions to end the business actors' effort in slowing down the investigations process and execution

${ }^{18}$ Black's Law Dictionary ("The decree is a judgment entered by consent of the parties whereby the defendant agrees to stop alleged illegal activity without admitting guild or wrongdoing. Agreement by defendant to cease activities asserted as illegal by government and upon approval of such agreement by the court, the government action against the defendant is dropped. The decree entered in an equity suit on consent of both parties, it is not properly a judicial sentence, but it is in the nature of a solemn contract or agreement of the parties, made under the sanction of the court and in effect an admission by them that the decree is a fact of the case, if such facts had been approved. It binds only the consenting parties and is not binding upon the court.") 
Maarif - Some Challenges to the Enforcement of the Competition Law in Indonesia

of KPPU's verdict. The right of business actors' to appeal on KPPU's verdict must however be respected. But in order to prevent a long process the appeal should just be directly submitted to the Supreme Court bypassing the district court. For that purpose, there must be revision in the law No.5/1999 since under the current system, appeal must be first submitted to the district court.

\section{Regional Government Officials}

During the hearing process of the bid rigging cases, the government official presence considered to be necessary for clarification on evidence and information obtained by the Commission. Experience shows that government officials on the upper level were sufficiently cooperative to appear before the Commission or even by only testifying or providing information in their office.

However differentexperience existed in the level of government official regent. During the investigation on the cattle procurement case in East Java, government officials related to the case were reluctant to collaborate and refused to be present before the Commission. They even refused to provide opportunity to the Commission to meet in their office to answer the questions. The officials even refuse to answer the Commission written questions even the indicted party has appear before the Commission.

During the telephone conversation between the Commission investigator and the government officials, it was revealed that the government officials did not know about the Commission existence and competency. Ironically, they think that the Commission is similar in function with the Non Governmental Organization or NGO. It is hard to speculate that the attitude reflected the arrogant manner of the government officials due to the new local autonomy approach. But there is no doubt that many officials failed to know and to understand that there is a Commission existed as an independent body with competency to implement and enforce Law No. 5/1999. Therefore, there is sufficient and urgent need of support from the local government officials and agencies to support the enforcement of Law No. 51/999 in broader scope and area.

From several possibilities above, the author holds the opinion that if these government officials understand the content of the Law No. 5 1999, they will be gladly and willingly cooperate with KPPU. To achieve that objectives there must be efforts to continuously socialize the Law within the environment of local government officials. But even so, there must be ruling in the form of Law that government officials are obligated to cooperate with KPPU in the case their explanations are needed. Administrative sanctions should be posed to those who violate this obligation.

\section{Case-Handling in the Region Level}

After observing around 40 cases, which are now under the Commission investigation, 3 of the cases are located in the region. The Commission has conducted several socialization of the law in few regions and found out that there is few local competition problems take place. There are ideas, which propose that the Commission should open their regional offices in several regions. The Commission thought about this idea and soon will look at its infrastructure and its staff capability. The Commission decided that in 2002 Budget to prepare the possibility to open the regional offices, however in the 
mean time, local competition problem would still be handle directly by the Commission office in Jakarta.

Out of the 3 local competition cases, 2 have been returned for remanded to the complainant due to incomplete paper work. Based on the experience in the investigation process, the Commission found many obstacles such as the budget and distance problem. This problem is also experienced by the complainant. While waiting for the set off of the regional commission office. few investigators from the regional offices proposed that the local investigators could conduct the investigation.

The author firmly believes that the opening of KPPU regional offices should be put in the priority list. The submission of the case handling to the police's investigators can result in the impression that business actors are going through the criminal examination process, in fact the violation of the Law No. $5 / 1999$ is an ethical business misconduct. In addition to that, the case handling submitted by to the police's investigators can result in webs of confusing procedures as there are two different ways of conducting investigation between KPPU and Police Department. For example, case clarification at KPPU takes place in an internal forum in a meeting room and not recorded in the official record.

To reduce the possibility that relevant parties from other regions of Indonesia cannot be present in the event of KPPU's examination, there are two approaches to this problem. KPPU can arrange transportation funding and accommodation for those obligated to be present in Jakarta or the alternative is for member of Commissioners to conduct hearing in that particular regions. The author prefers the first alternative as it requires less fund- ing compared to members of Commissioners to conduct a hearing in the regions.

\section{Witness or Petitioner}

During the enforcement of Law No. $5 / 1999$ process, there are 2 parties who play important role, the petitioner and the witness. Petitioner submitted their information or claim on the allegation of violation of the law with preliminary evidence. Witness would function by submitting their information as evidence either to support or to rebut the allegation.

From many occasions, there are lots of sources willing to submit report or claim but failed to believe that their information would one day gives impact or might injured themselves. In few cases, witnesses even endure the risk to be terminated from their office because of their report to the Commission. However, in most cases, petitioner are usually the competitors who felt harmed by their competitor behavior.

Law No. 5/1999 did not confer any competency to the Commission to provide the witness protection unless the protection to the identity of the petitioner which will not be revealed to the public. Similar problem could also exist with the witness. If there is guarantee from the Commission, few witnesses willing to appear and give information before the Commission. Many agreed after clear support and most of them were conducted without written testimony and merely based on informal or recorded investigation.

Therefore the challenge is to ensure that all parties should be willing to report any wrongdoing or violation of Law No. 5/ 1999 to the Commission and also should be willing to testify or appear before the Commission during the investigation process. In this case, the approach of settle- 
Maarif $\rightarrow$ Some Challenges to the Enforcement of the Competition Law in Indonesia

ment through leniency program seems to be the best alternative that the Commission can apply. The Commission should design this approach in scrupulously with the objective of changing the business actor behavior without go through legal process. The Antitrust Division of the Department of Justice (DoJ) in the United States has introduced this program and even provides immunity to the business actors who are willing to collaborate by submitting all information required by the Commission. For example in cartel case, the prerequisite are the business actor should be the one who allegedly is the wrongdoer and has reported to the Department of Justice. The office should be able to use and rely on the report to be used as the tool to dismantle the cartel. If there are 5 cartel members existed, then the other 4 will be taken according to the due process of law while the first one would be granted amnesty. Most cartel cases or around 80 percent could be resolved through leniency program, which reflects good result that the Commission is now thinking to adopt the mechanism.

The author agrees that the Law should permit witness to be given a legal protection as it is an important tool for certain parties who are obligated to testify since it is ruled in the Law No. 5/1999. Sanction for the violation of the Law No. 5/1999 for not testifying in KPPU hearing may result in the submission of the case to the police investigator, and therefore, it is only fair that witness should be legally protected in all circumstances.

\section{Written Evidence}

The Commission also found many interesting issues during its monitoring tasks. Few of the Commission resources informed that there is a legal relationship existed between the producers, suppliers with its distributors or agents which could not be regulated under written agreement. This practice is somehow different compare to prior enactment of LawNo. 5/1999. Prior to enactment of the law, business relationship was standardized through written agreement, however the attitude now has changed. This can become a challenge to the Commission in the effort to maintain good behavior in the business practices and not merely to deal with the intention to omit the evidence.

There should be continuous socialization to all business actors in which emphasis should be given that competition is not only good for the consumers but also the producers. Comprehension on competition issues will transform behavior of business actors from those of eliminating instrument of evidence to an elimination of an unfair business act. With respect to the evidence, written evidence is just one tool to reach a verdict but it does not dismiss the notion of using other evidence.

\section{The Role of Legal Counsel}

In the effort to guarantee the due process of law, the parties who appear before the Commission shall be eligible to be accompanied by their legal counsel or lawyer. In practice, many use this opportunity and some did not exercise their right at all. All questions should be answered by the parties and with the approval from the Commission Assembly; the party could consult with their lawyer before answering the questions from the investigator.

During the ongoing practice, the parties under investigation responded to most of the Commission Assembly questions. Most of the parties who have been questioned were actually the parties involved in the allegedly wrong behavior. However, there are occasions that the parties 
exercised their right to consult with their lawyer before responding to the Commission questions. Mostly are changing their answer after consultation with their lawyers.

Similar things existed when the parties were required to sign the investigations report. In general rules, the Commission Assembly would repeat the contents of the report for verification prior to signing by the parties. However, in the course of the signing, many times happens that the parties refused to sign with the reason of inconsistency in their investigation and what is written in the report. Then the parties would consult with their lawyer and subsequent to that, they will be willing to sign under the circumstances if the lawyer agreed to the contents of the report.

Therefore, the challenge is the change the attitude. The parties are free to exercise their right to be accompanied by their lawyers and this is granted by the law. However, this course does not mean to encumber the due process of law ever, but merely to uphold the rights of the parties to be treated equally and fairly before the law and not to hinder.

They are not easy to be achieved. But a clear definition on the rights of legal adviser in the examination of cases at KPPU will prevent the effort of lawyers trying to slow down the process. Therefore there must be effort to improve the procedures of case examination at the KPPU.

\section{Conclusion}

When competition law has not defined the main objective or the purpose of the law, having too many purposes or even conflicting purposes, the law would not be. as effective as it ought to be. Many interpretations would lead to inconsistency in the enforcement or application of the law. If competition law or Law Number 5 of 1999 cannot be able to serve its purposes, it may lead not only to economic in efficiency but could lead to economic distortion and business community would not have clear guidance on their conduct.

The Commission and the courts would play major role to resolve the interpretation of the law. The government also plays a substantial role by enforcing the law would impose the discipline of competition in the market. Indonesia is facing great changing to the system of market economy and this economic system efficiency and fair competition are two underpinnings that could be used through the market to achieve the goals. Although Indonesian competition law has many provisions that could lead to various interpretations, however, considered, that this is only the beginning to understand the new concept of competing with the support of the legal tools. The Commission, judges, and prosecutors would face pressure to try to interprets between the choice of fairness, economic efficiency, and protecting of small medium business as instructed in the Article 33 of 1945 Constitution.

Other major obstacles encountered by the law enforcers are the ambiguities of the law, the question of the procedural law, and the lack of comprehension of the new subject. The answer would not be found immediately. The Commission and the law enforcers would have to learn from the process by strengthening the knowledge, which in the long run could be reflected in their decisions. This may lead to the improvement of the procedural law as well. There would be certainly an open alternative to amend the law in the future, however, amendment is not the ultimate way to improve the law. Developing the understanding the concept of competition, 
Maarif Some Challenges to the Enforcement of the Competition Law in Indonesia

understanding the economic efficiency and the consumer welfare would have to go along with the improvement of the procedural law and the ability of the law enforcers.

Although there are still questions that need to be answered concerning the competition law's meaning and the enforcement process, through the Commission's work, court cases, and judges' decisions, the future of the law may lead to more competitive markets in Indonesia and the improved economic welfare of the Indonesian people.

There are certainly great challenges faced during the course of less than four years time of enactment of Law No. 5/ 1999 in Indonesia. The law encounters both conceptual and enforcement aspects. However, it is understood that this would be a normal assessment in Indonesia legal reform especially competition law is considered to be a newly adopted law. Therefore, the Commission holds strong motivation and committed that the challenge could be prevailed by the support of the legal reform and support of the society to achieve the objective and purpose of Law No.5/1999. This optimism can be achieved if certain rules that are obscure in nature that could cause different interpretations be revised in a concise manner.

\section{References}

Adiwiyoto, B. P. 2001. Analysis of the objectives and purposes of Law No. 5/1999. Policy Paper presented to KPPU (July 20 2 ) [unpublished]. Jakarta.

American Bar Association. 1977. Section of Antitrust Law, Antitrust Law Developments (Fourth). Section of Antitrust. Chicago, Il.

Basri, F.H. 2002. Attitude towards enforcement of law No. 5/1999 and effectiveness of the KPPU role. Paper presented on the panel at LKPU FHUI (March 26) [unpublished]. Jakarta.

Brietzke, P. H. 1999. Komisi persaingan usaha di Negara-negara lain. Papei.presented at Seminar under collaboration between University of Hasanuddin, Ujung Pandang, University of Udayana, Bali, and University of San Francisco, Ujung Pandang [unpublished].

Fox, E. M. 2002. Indonesian's Law No. 5 of 1999: A substantive analysis of the law against monopolistic practice and unfair business competition and of the place of the law in the world competition system. A paper presented at seminar on Investment and Competition Policy (January 11) [Unpublished]. Jakarta.

Hansen, K., P. W. Heermann, W. Kartte, H. W. Miek Litz, W. Pfletschinger, F. J. Sacker, and H. Santer. 2002. Law Concerning Prohibition of Monopolisitic Practices and Unfair Business Competition (2 ${ }^{\text {nd }}$ Ed.). Jakarta: Katalis.

Kaplow, A,. 1997. Antitrust Analysis: Problems, Text, and Cases. Boston: Aspen Law \& Business.

KPPU. 2001. Press Release (December). 
Maarif, S. 2002. UU No. 5 tahun 1999 tentang larangan praktek monopoli dan persaingan usaha tidak sehat. Paper presented at the Supreme Court Justice Orientation (January) [Unpublished). Jakarta.

2002. Few notes on law No. 5/1999 enforcement. Paper presented at Panel Discussion in Jakarta (March 26) [unpublished].

Maier, M. 2001. Introduction to competition law and policy, and Indonesia's competition law and business competition commission. Paper presented to the Supreme Court of the Republic of Indonesia (September 6-7) [unpublished]. Jakarta.

. 2001. Introduction to the Federal Trade Commission, its organization and interaction with other governmental entities. Paper presented to the Commission for the Supervision of Business Competition (KPPU) (May 10) [unpublished]:

PBC. 2000. Report on the business actor awareness of law number 5 of 1999, research. Partnership for Business Competition (March). Georgetown University, PEG and USAID.

PBC. 2001. Compilation of the training for judges. Partnership for Business Competition (July and October) [unpublished]. Jakarta and Semarang, October 2001.

Posner, R. A. 1992. Economic Analysis of the Law. Little, Boston: Brawn and Company.

Sjahdeini, S. R. 2000. Larangan praktek monopoli dan persaingan usaha tidak sehat. Business Law Journal 10.

Silalahi, M. U. 2001. Persaingan usaha tidak sehat dan perbuatan tidak jujur. Business Law Journal 14.

Squery, S. J. 1995. Government investigation and enforcement: Antitrust division (Practising Law Institute). Law and Practice Course Handbook Series (New York, NY: Antitrust Law Institute.

Wie, T. K. 2000. Kebijaksanaan persaingan di Indonesia dan undang-undang antimonopoli dan persaingan sehat yang baru. Paper presented at the Seminar of Kebijaksanaan Persaingan dan Reformasi Ekonomi (22-23 May 22-23) [unpublished]. Jakarta. 